Research Article

\title{
Annual Variation in Soil Enzyme Activity in a Paddy Field: Soil Temperature and Nutrient Availability Are Important for Controlling Enzyme Activities
}

\author{
Takashi Kunito ${ }^{(D)}{ }^{1}$ Takashi Shiroma, ${ }^{1}$ Hitoshi Moro, ${ }^{1}$ and Hirotaka Sumi ${ }^{2}$ \\ ${ }^{1}$ Department of Environmental Sciences, Faculty of Science, Shinshu University, 3-1-1 Asahi, Matsumoto 390-8621, Japan \\ ${ }^{2}$ Department of Biological Chemistry, College of Bioscience and Biotechnology, Chubu University, 1200 Matsumoto-cho, Kasugai, \\ Aichi 487-8501, Japan \\ Correspondence should be addressed to Takashi Kunito; kunito@shinshu-u.ac.jp
}

Received 5 June 2018; Revised 22 August 2018; Accepted 19 September 2018; Published 10 October 2018

Academic Editor: Rafael Clemente

Copyright ( $\odot 2018$ Takashi Kunito et al. This is an open access article distributed under the Creative Commons Attribution License, which permits unrestricted use, distribution, and reproduction in any medium, provided the original work is properly cited.

Annual variations in enzyme activities involved in carbon $(\mathrm{C})$, nitrogen $(\mathrm{N})$, phosphorus $(\mathrm{P})$, and sulfur $(\mathrm{S})$ cycling and soil physicochemical properties were examined in a Japanese paddy field. All the enzyme activities determined at the field soil temperature (range, $\left.2.2^{\circ} \mathrm{C}-28.3^{\circ} \mathrm{C}\right)$ increased exponentially with soil temperature $(p<0.001)$. Significant negative correlations were found between Bray-2P concentration and the ratio of acid phosphatase to $\beta$-D-glucosidase activity (Spearman $r=-0.631$, $p=0.005)$ and between total $\mathrm{N}$ and the ratio of $\mathrm{L}$-asparaginase to $\beta$-D-glucosidase activity $(r=-0.612, p=0.007)$, suggesting that in accordance with the resource allocation model, acid phosphatase and L-asparaginase were synthesized by microorganisms depending on the temporal changes in soil $\mathrm{P}$ and $\mathrm{N}$ availability. These results suggest the significance of soil temperature in controlling in situ enzyme activities in paddy soil and also that the stoichiometry of enzyme activities associated with C, N, and P acquisition reflects the soil nutrient availability.

\section{Introduction}

Rice cultivation in paddy soils is a vital component of global agriculture $[1,2]$; rice is the main staple food for more than half of the world's population and it provides about $20 \%$ of the world's dietary energy supply $[3,4]$. Paddy soils experience temporal variation in redox conditions: paddy fields are kept flooded during the rice growing season, whereas they are drained during the nongrowing season. Variations in redox conditions cause complicated biogeochemical processes in paddy soils, mostly mediated by microorganisms [5-8], and lead to fluctuations in the soil nutrient availability [2]. The fluctuations in nutrient availability influence microbial activities in paddy soils, and vice versa.

Microorganisms produce various enzymes that are involved in organic matter degradation [9] and therefore influence nutrient cycling and soil fertility [10]. In spite of the significant roles of soil enzymes in nutrient cycling in paddy fields, limited information is available about the annual dynamics of enzyme activities and the factors controlling them in paddy soils. In the present study, we hypothesized that enzyme activities involved in carbon (C), nitrogen $(\mathrm{N})$, phosphorus $(\mathrm{P})$, and sulfur $(\mathrm{S})$ cycling would vary according to the fluctuations in the soil nutrient availability caused by flooding and draining in paddy fields. The annual variations in enzyme activities and soil physicochemical properties were determined and compared to reveal possible links between them.

\section{Materials and Methods}

2.1. Soil Sampling. Soil samples were collected 18 times from November 2007 to October 2008 from a paddy field $\left(1400 \mathrm{~m}^{2}\right)$ in Matsumoto, Nagano Prefecture, Japan. The mean annual temperature was $11.8^{\circ} \mathrm{C}$, and mean annual precipitation was $1,031 \mathrm{~mm}$. The soil was classified as Gray Lowland soil in the Japanese system, which corresponds to Gleyic Fluvisol in the World Reference Base classification. 
The paddy field received cow manure $\left(1.43 \mathrm{~kg} \cdot \mathrm{m}^{-2}\right)$, compost $\left(0.17 \mathrm{~kg} \cdot \mathrm{m}^{-2}\right)$, and bone meal $\left(0.04 \mathrm{~kg} \cdot \mathrm{m}^{-2}\right)$ on May $1,2008$. The field was flooded on May 6, and rice seedlings were transplanted on May 17. The field remained flooded until late August and was then drained. The rice plants were harvested on September 25.

On each sampling date, soil sampling was conducted at around 2 p.m., and air and soil temperatures were measured in the paddy field. Soil samples were collected from five plots to $15 \mathrm{~cm}$ depth on each sampling occasion. After putting each sample into a polyethylene bag, air and water were removed from the bag, and then the samples were transported to the laboratory within $30 \mathrm{~min}$ after collection. Soil redox potential (Eh) and $\mathrm{pH}$ were measured for three soil samples as soon as possible; for the other measurements, the same amount of five soil samples were pooled and mixed together as a composite sample, and then they were stored at $-80^{\circ} \mathrm{C}$ in bottles purged with $\mathrm{N}_{2}$ gas until analysis.

2.2. Soil Physicochemical Analyses. Eh was measured as described in Onikura and Goto [11]. In brief, deoxygenated water was gently added to the wet soil, and then a Pt electrode was inserted into the soil. After leaving it to stand for $1 \mathrm{~h}$ under $\mathrm{N}_{2}$ gas, Eh was determined using an Eh meter (PRN-41, Fujiwara Scientific Company, Tokyo, Japan) with a Pt- $\mathrm{AgCl}$ combination reference electrode. Soil $\mathrm{pH}$ was measured with a glass electrode in the water just above the soil. We did not correct the Eh for $\mathrm{pH}$ in this study, because there is a wide range of reported changes in Eh per unit of $\mathrm{pH}[12]$.

Acid-volatile sulfide (AVS) was measured by the coldacid purge and trap technique described by Allen et al. [13]. AVS is defined as the reactive fraction of sulfide in soil that releases $\mathrm{H}_{2} \mathrm{~S}$ when exposed to cold $\mathrm{HCl}$; it includes dissolved sulfide species and metastable iron sulfide minerals [14]. Briefly, the wet soil was treated with deoxygenated $\mathrm{HCl}$, adjusted to a final concentration of $1 \mathrm{M}$, for $30 \mathrm{~min}$ in the reactor under a continuous flow of $\mathrm{N}_{2}$ gas, and the evolved $\mathrm{H}_{2} \mathrm{~S}$ was trapped in $0.5 \mathrm{M} \mathrm{NaOH}$. The sulfide content in the trap was measured by the methylene blue spectrophotometric technique. The recovery of sulfide added as $\mathrm{Na}_{2} \mathrm{~S} \bullet 9 \mathrm{H}_{2} \mathrm{O}$ to the reactor was $116.5 \pm 19.6 \%(n=4)$. Exchangeable manganese $(\mathrm{Mn})$ was extracted from the wet soil with deoxygenated $0.05 \mathrm{M} \mathrm{CaCl}_{2}$ for $24 \mathrm{~h}[15,16]$ under $\mathrm{N}_{2}$ gas and then determined with an atomic absorption spectrometer (Perkin Elmer 5100 PC, Tokyo, Japan). Mn was selected as a metal sensitive to soil reduction [17]. Modified Bray-2P was extracted from the wet soil using deoxygenated dilute acid fluoride $\left(0.03 \mathrm{M} \mathrm{NH}_{4} \mathrm{~F}, 0.1 \mathrm{M} \mathrm{HCl}\right)$ at a $1: 20$ soil : solution ratio $(\mathrm{w} / \mathrm{v})$ [18]. Concentrations of inorganic $\mathrm{P}(\mathrm{Pi})$ in the extracts were determined by the ammonium molybdate-ascorbic acid method [19]. In the colorimetric determination of Pi for the extract of the modified Bray-2 test, fluoride can interfere with color formation, and thus boric acid was added to form noninterfering fluoroborate [18]. For total C and $\mathrm{N}$ measurements, air-dried soil samples were used; the amounts were determined using an NC analyzer (Thermo Finnigan Flash EA1112, Thermo Fisher
Scientific, Waltham, MA, USA). These analyses were performed in triplicate for each sample, and the mean values are expressed on a dry weight basis.

2.3. Soil Enzyme Analyses. We measured soil enzyme activities involved in $\mathrm{C}, \mathrm{N}, \mathrm{P}$, and $\mathrm{S}$ cycling in soils stored at $-80^{\circ} \mathrm{C}$. $\beta$-D-glucosidase activity was chosen as a representative $\mathrm{C}$-acquiring enzyme because this enzyme is involved in hydrolysis of cellobiose, the main product in hydrolysis of cellulose by cellulases [20], and it was measured with $p$ nitrophenyl- $\beta$-D-glucopyranoside as the substrate in a modified universal buffer (MUB) (tris(hydroxymethyl) aminomethane, $2.42 \mathrm{~g}$; maleic acid, $2.32 \mathrm{~g}$; citric acid, $2.8 \mathrm{~g}$; boric acid, $1.26 \mathrm{~g}$; and distilled water, $1 \mathrm{~L}$ ) at $\mathrm{pH} 6.0$ [20]. L-asparaginase activity was measured with L-asparagine as the substrate in a phosphate buffer at $\mathrm{pH} 7.6$ [21]. $\mathrm{L}$-asparaginase was selected as the $\mathrm{N}$-acquiring enzyme, because it was reported that among several $\mathrm{N}$-acquiring enzymes, L-asparaginase was the most representative of the $\mathrm{N}$ availability in soils [22]. Acid phosphatase activity was determined as the $\mathrm{P}$-acquiring enzyme with $p$-nitrophenyl phosphate as the substrate in a MUB at $\mathrm{pH} 6.5$ [20], because this enzyme plays an important role in $\mathrm{P}$ cycling in soils (e.g., $[23,24])$. Arylsulfatase activity, which is partly responsible for S cycling in soils [20], was chosen as a representative $S$-acquiring enzyme and was determined with $p$ nitrophenyl sulfate as the substrate in an acetate buffer at $\mathrm{pH}$ 5.8 [20]. These assays were conducted in triplicate at the field soil temperature when the soil was collected. A standard curve was prepared on each occasion of measurement. The activities are expressed on a dry weight basis.

\section{Results and Discussion}

3.1. Annual Variations in Soil Physicochemical Properties. The lowest soil temperature $\left(2.2^{\circ} \mathrm{C}\right)$ was observed on February 24 , and the highest $\left(28.3^{\circ} \mathrm{C}\right)$ was recorded on August 8 (Figure 1). Soil total $\mathrm{C}$ and $\mathrm{N}$ contents were slightly elevated during June and July. This increase might reflect a large input of organic matter through rice plants [25] and algae [26] in this period. Some soil physicochemical properties were drastically changed by water management practices. Soil Eh began to decrease after flooding on May 6 because of the oxygen depletion and stayed stable $(-11 \pm 31 \mathrm{mV}$ to $53 \pm$ $34 \mathrm{mV}$ ) under the flooded condition. Simultaneously with the decline in Eh, exchangeable $\mathrm{Mn}$ and Bray-2P concentrations and $\mathrm{pH}$ increased in the soil. The increase in $\mathrm{pH}$ with reduction in soil $\mathrm{Eh}$ is a well-known phenomenon (e.g., [16, 27]), which is caused by proton consumption through the formation of various reductants [28]: Ox $+n \mathrm{e}^{-}+m \mathrm{H}^{+}=\mathrm{Red}+(m / 2) \mathrm{H}_{2} \mathrm{O}$, where $\mathrm{Ox}$ is the oxidized species and Red is the reduced species, and $m$ and $n$ are stoichiometric factors. The increase in exchangeable Mn concentration with reduction in soil Eh results from the reduction of $\mathrm{Mn}(\mathrm{IV})$ oxides to $\mathrm{Mn}$ (II) primarily by microorganisms $[5,29]$. An increase in Bray-P concentration by soil flooding was also reported in other studies $[30,31,32]$. Such an enhancement of P availability has long 


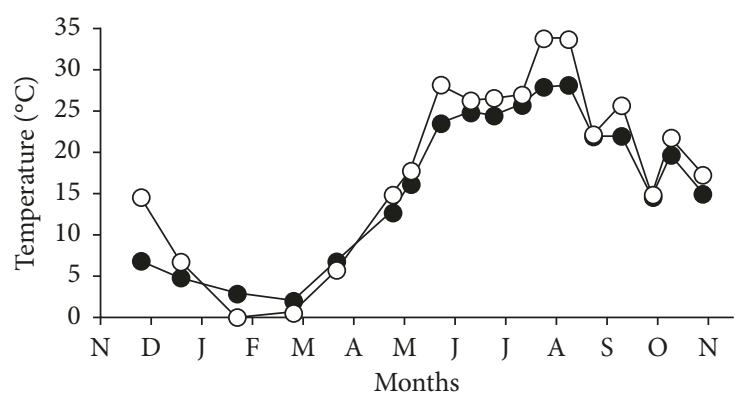

(a)

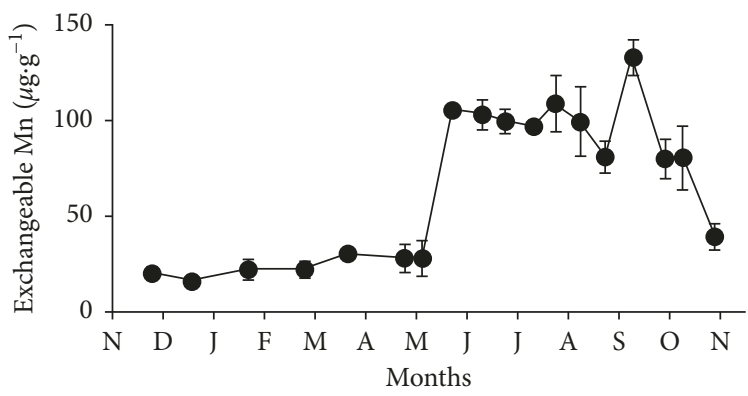

(c)

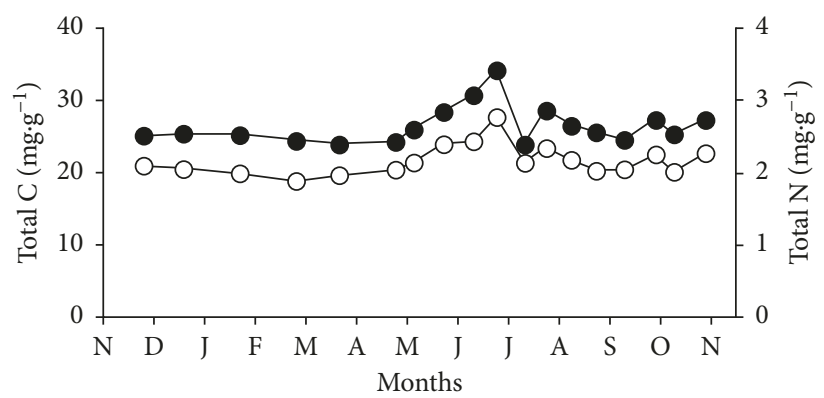

(e)

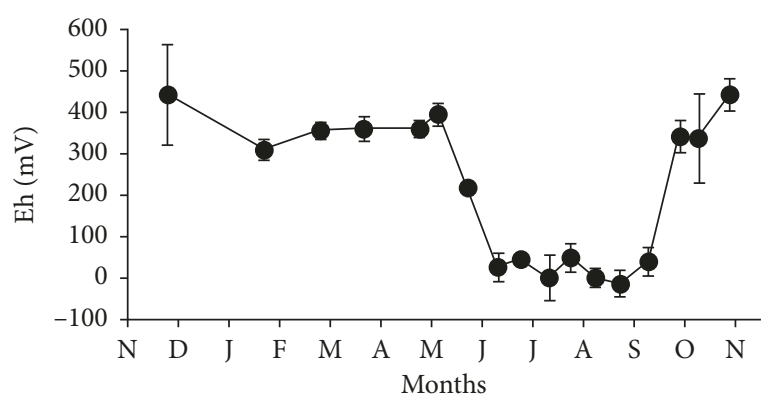

(b)

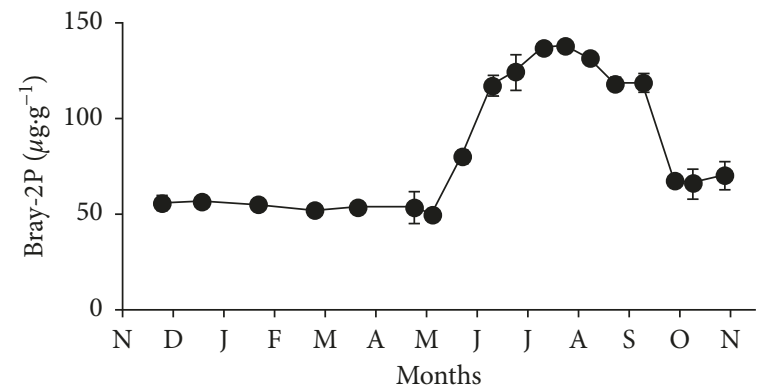

(d)

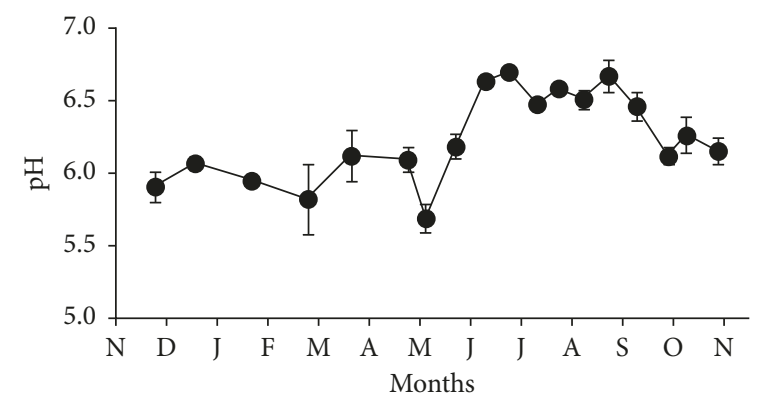

(f)

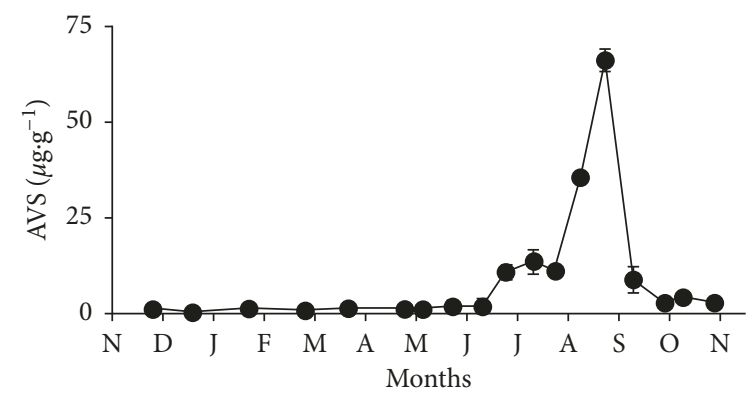

(g)

FIgURE 1: Annual variations in soil physicochemical properties in a paddy field. (a) Air and soil temperatures. Filled circle, soil temperature; open circle, air temperature; (b) soil Eh; (c) exchangeable Mn; (d) Bray-2P; (e) total C and N. Filled circle, total C; open circle, total N; (f) soil $\mathrm{pH}$; (g) acid-volatile sulfide. Data points represent means, and the error bars represent standard deviations.

been known in flooded paddy soils (e.g., [33, 34], primarily caused by the reduction of Fe(III) compounds holding $\mathrm{P}$ on their surfaces and by reduction of insoluble ferric phosphate to more soluble ferrous phosphate $[2,35])$.

On September 28, a steep rise in Eh concurrent with soil draining caused a rapid drop in Bray-2P concentration from $119 \pm 5$ to $68 \pm 1 \mu \mathrm{g} \cdot \mathrm{P} \cdot \mathrm{g}^{-1}$ (Figure 1). In contrast, exchangeable $\mathrm{Mn}$ concentration declined gradually with soil oxidation, and an increased concentration of exchangeable Mn was still observed on October 9. Gotoh and Yamashita [36] and Phillips [37] also observed the slow reoxidation of $\mathrm{Mn}(\mathrm{II})$ formed in the reduced soil. These results indicate that $\mathrm{Mn}$ (IV) oxides are rapidly reduced by flooding, but the reoxidation of $\mathrm{Mn}$ (II) seems to be slow during the oxidation of anoxic soils. In stark contrast, the AVS concentration increased very slowly after flooding 


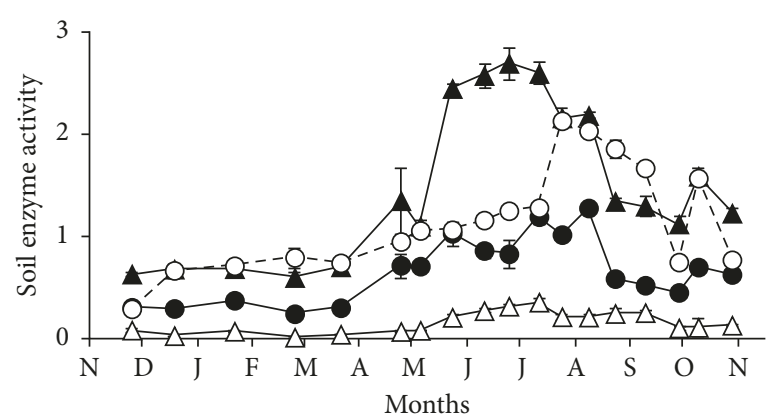

(a)

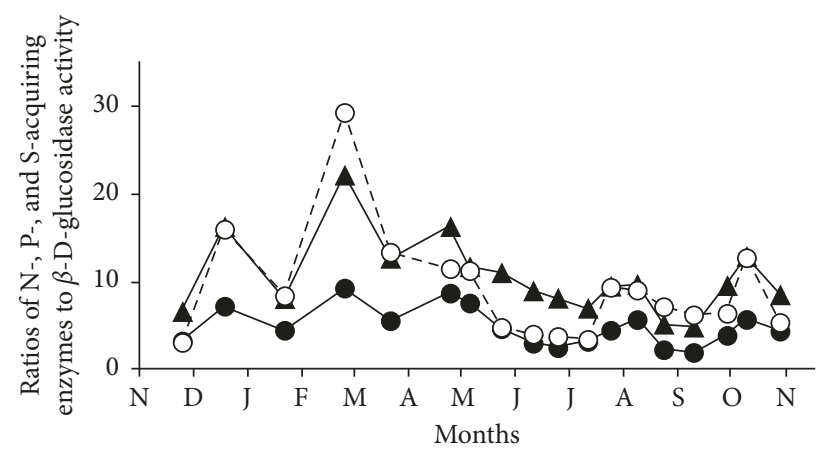

(b)

FIgUre 2: Annual variations in enzyme activities involved in $\mathrm{C}, \mathrm{N}, \mathrm{P}$, and S cycling (a) and the ratios of N-, P-, and S-acquiring enzymes to $\beta$-D-glucosidase activity (b). (a) Filled triangle, arylsulfatase $\left(\mu \mathrm{mol} \mathrm{p}\right.$-nitrophenol $\left.\mathrm{g}^{-1} \cdot \mathrm{h}^{-1}\right)$; open circle, $\mathrm{L}$-asparaginase $\left(\mu \mathrm{mol} \mathrm{NH}_{4}{ }^{+}-\mathrm{N}\right.$ $\left.\mathrm{g}^{-1} \cdot \mathrm{h}^{-1}\right)$; filled circle, acid phosphatase $\left(\mu \mathrm{mol} \mathrm{p}\right.$-nitrophenol $\left.\mathrm{g}^{-1} \cdot \mathrm{h}^{-1}\right)$; open triangle, $\beta$-D-glucosidase $\left(\mu \mathrm{mol} \mathrm{p}\right.$-nitrophenol g $\left.{ }^{-1} \cdot \mathrm{h}^{-1}\right)$. $(\mathrm{b})$ Open circle, ratio of L-asparaginase to $\beta$-D-glucosidase activity; filled triangle, ratio of arylsulfatase to $\beta$ - $\mathrm{D}$-glucosidase activity; filled circle, ratio of acid phosphatase to $\beta$-D-glucosidase activity. Data points represent means, and the error bars represent standard deviations.

(beginning a month later than that of exchangeable $\mathrm{Mn}$ and Bray-2P) and decreased sharply from $66.4 \pm 2.8$ to $9.2 \pm$ $3.3 \mu \mathrm{g} \cdot \mathrm{g}^{-1}$ on September 9 , more than a month ahead of the decline of exchangeable Mn. This behavior of AVS can be explained by the low Eh $(<0 \mathrm{mV})$ at which sulfide is formed through microbial respiratory sulfate reduction [5] and by the rapid oxidation of sulfide via some oxidizable substances [13].

3.2. Soil Enzyme Activities. In this study, enzyme activities were determined at the field soil temperature when the soil was collected to reflect the annual changes of in situ activity in the paddy field. All the activities of four enzymes were high in summer (Figure 2(a)) and increased exponentially with soil temperature (Figure 3). Because soil temperature correlated positively with total C, total N, Bray-2P, and $\mathrm{pH}$ and negatively with Eh, most of these variables also correlated with enzyme activities (Table 1). However, these correlations were weaker than those between soil temperature and enzyme activities. These results might imply that soil temperature had a larger influence on in situ enzyme activities than flooding.

The effects of season and flooding/draining condition on the enzyme pool might be small in the paddy field, because the exponential relationship between enzyme activities and soil temperature (Figure 3) could be explained by temperature sensitivity of the structure and catalytic activity of the enzyme itself [38], which is described from first principles of thermodynamics. Inconsistent results have been reported regarding the effects of flooding and season on enzyme activities among soils and among enzymes in laboratory soil incubation studies [39, 40,41] and field studies [42, 43]. Ishida and Shiraishi [42] found elevated levels of saccharase but similar levels of amylase activities under flooded conditions in summer compared with those under drained conditions in winter in a paddy field, whereas Kanazawa [43] reported a slight decrease in $\beta$-D-glucosidase and $N$-acetyl$\beta$-glucosaminidase activities during the flooded period when compared with other periods in a paddy field (in both studies, enzyme activities were measured at a single reference temperature, not at the field soil temperature). High enzyme activity during the flooded period might be the result of the large input of organic matter from rice plants and algae as mentioned above. The decreased activity associated with flooding would not be related to the disappearance of $\mathrm{O}_{2}$ because of the insensitivity of hydrolase to $\mathrm{O}_{2}$ levels [44] but might be caused by the accumulation of phenolic compounds in the flooded paddy soil [44-46]. Alternatively, the decreases in the enzyme activities under flooded conditions might be a consequence of decreased microbial biomass size [39]. Further studies are necessary to understand the influence of flooding and season on enzyme activities and pools in paddy fields.

Variation in the stoichiometry of enzyme activities associated with nutrient acquisition can be explained by the resource allocation model for extracellular enzyme synthesis $[47,48]$ in which microorganisms will preferentially allocate their resources to enzymes for acquiring an element limiting their productivity. In aerobic agricultural and forest soils, the ratio of phosphatase to $\beta$-D-glucosidase activity and the ratio of $\mathrm{L}$-asparaginase to $\beta$-D-glucosidase activity reflect $\mathrm{P}$ $[49,50]$ and $\mathrm{N}[22,50]$ bioavailability, respectively. Thus, in the present study, we determined these enzyme ratios to evaluate annual variation in bioavailability of nutrients in the paddy field. The ratios of L-asparaginase to $\beta$-Dglucosidase activity and arylsulfatase to $\beta$-D-glucosidase activity exhibited similar temporal patterns: these ratios were generally higher in winter than in summer (Figure 2). In contrast, annual variation in the ratio of acid phosphatase to $\beta$-D-glucosidase activity was small. In agreement with the results of aerobic agricultural and forest soils [22, 49, 50], significant negative correlations were observed between Bray-2P concentration and the ratio of acid phosphatase to $\beta$-D-glucosidase activity (Spearman $r=-0.631, p=0.005$ ) and between total $\mathrm{N}$ and the ratio of L-asparaginase to $\beta$-Dglucosidase activity $(r=-0.612, p=0.007$; Figure 4$)$, which were comparable to those in previous studies. Therefore, it is 


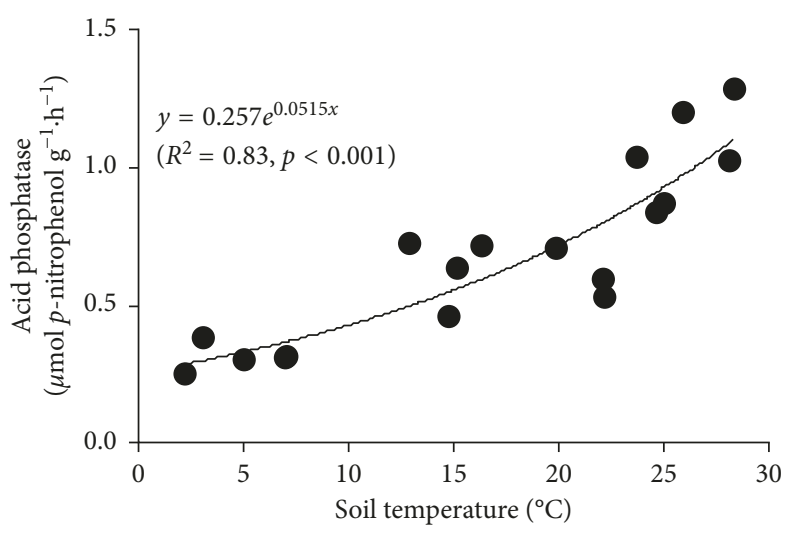

(a)

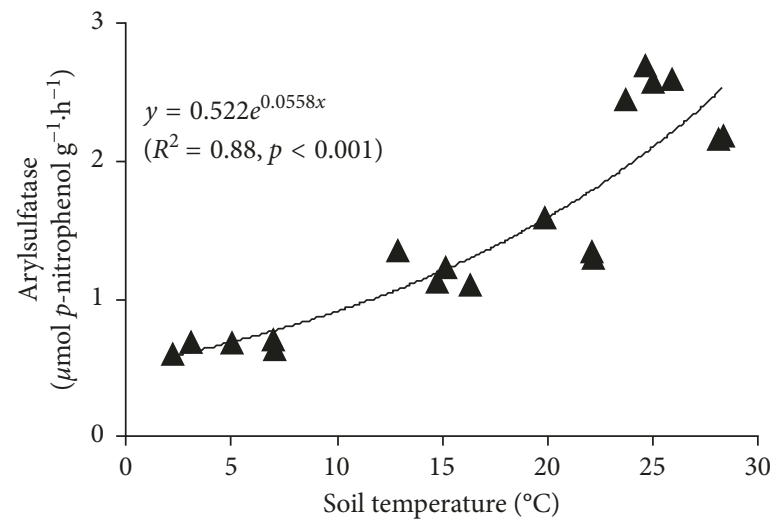

(c)

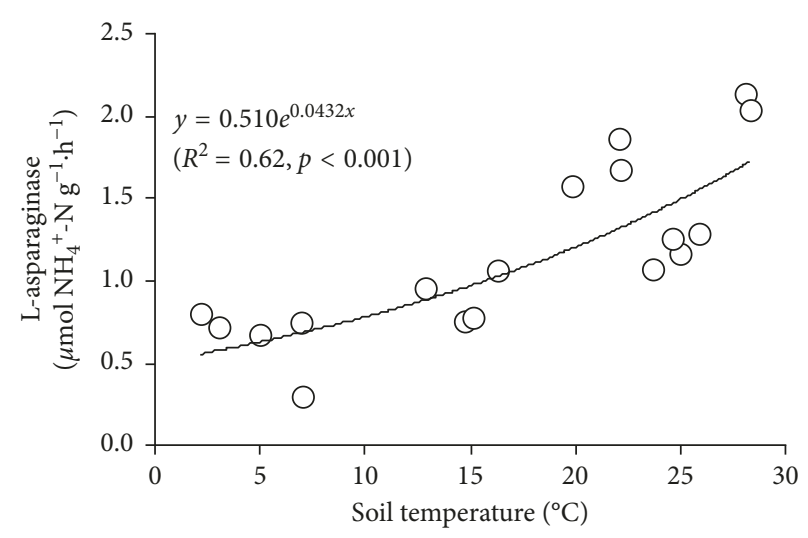

(b)

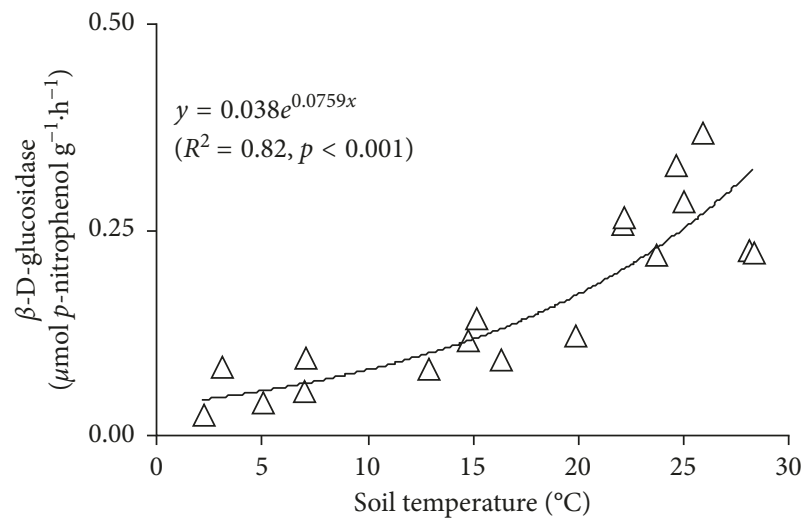

(d)

FIgURE 3: Relationships between soil temperature and enzyme activity in paddy soil. (a) Acid phosphatase; (b) L-asparaginase; (c) arylsulfatase; (d) $\beta$-D-glucosidase.

TABLE 1: Spearman rank correlation coefficients between soil properties and enzyme activities.

\begin{tabular}{|c|c|c|c|c|c|c|c|c|c|}
\hline & Soil temperature & Total N & Total C & Bray-2P & Eh & $\mathrm{pH}$ & Arylsulfatase & Acid phosphatase & $\beta$-Glucosidase \\
\hline Total N & $0.666^{* *}$ & & & & & & & & \\
\hline Total C & $0.482^{*}$ & $0.820^{* *}$ & & & & & & & \\
\hline Bray-2P & $0.856^{* *}$ & $0.564^{*}$ & 0.416 & & & & & & \\
\hline $\mathrm{Eh}$ & $-0.723^{* *}$ & -0.216 & -0.206 & $-0.757^{* *}$ & & & & & \\
\hline $\mathrm{pH}$ & $0.808^{* *}$ & $0.472^{*}$ & 0.453 & $0.868^{* *}$ & $-0.794^{* *}$ & & & & \\
\hline Arylsulfatase & $0.880^{* *}$ & $0.631^{* *}$ & 0.439 & $0.740^{* *}$ & $-0.659^{* *}$ & $0.825^{* *}$ & & & \\
\hline Acid phosphatase & $0.893^{* *}$ & $0.649^{* *}$ & 0.414 & $0.643^{* *}$ & $-0.534^{*}$ & $0.610^{* *}$ & $0.897^{* *}$ & & \\
\hline$\beta$-Glucosidase & $0.874^{* *}$ & $0.608^{* *}$ & 0.414 & $0.876^{* *}$ & $-0.748^{* *}$ & $0.856^{* *}$ & $0.827^{* *}$ & $0.701^{* *}$ & \\
\hline L-asparaginase & $0.839^{* *}$ & 0.265 & 0.273 & $0.717^{* *}$ & $-0.757^{* *}$ & $0.759^{* *}$ & $0.713^{* *}$ & $0.695^{* *}$ & $0.709^{* *}$ \\
\hline
\end{tabular}

${ }^{*}, p<0.05 ;^{* *}, p<0.01$.

suggested that acid phosphatase and L-asparaginase were synthesized by microorganisms depending on the temporal changes in soil $\mathrm{P}$ and $\mathrm{N}$ availability, although the microbial community, in particular the active microbial community, is known to vary substantially with redox conditions in paddy soils $[5,7,51]$.

\section{Conclusions}

Exchangeable Mn, Bray-2P, and AVS concentrations and $\mathrm{pH}$ increased as the soil became more reduced under flooded conditions, and vice versa under drained conditions in the paddy field. Contrasting behavior was observed between exchangeable Mn and AVS: the exchangeable Mn concentration increased simultaneously with the decline in Eh after flooding and declined gradually with soil oxidation after draining, whereas the AVS concentration increased very slowly after flooding and decreased sharply after draining. Enzyme activities determined at the field soil temperature were high in summer, with the activity increasing exponentially with soil temperature. The ratio of acid phosphatase to $\beta$-D-glucosidase activity increased with a decrease in Bray-2P concentration and the ratio of L-asparaginase to $\beta$-D-glucosidase activity increased with a decrease in total $\mathrm{N}$, 


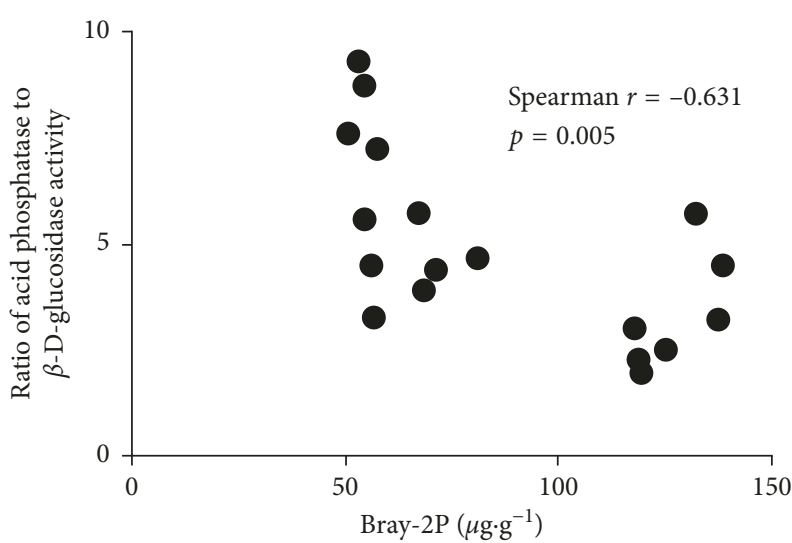

(a)

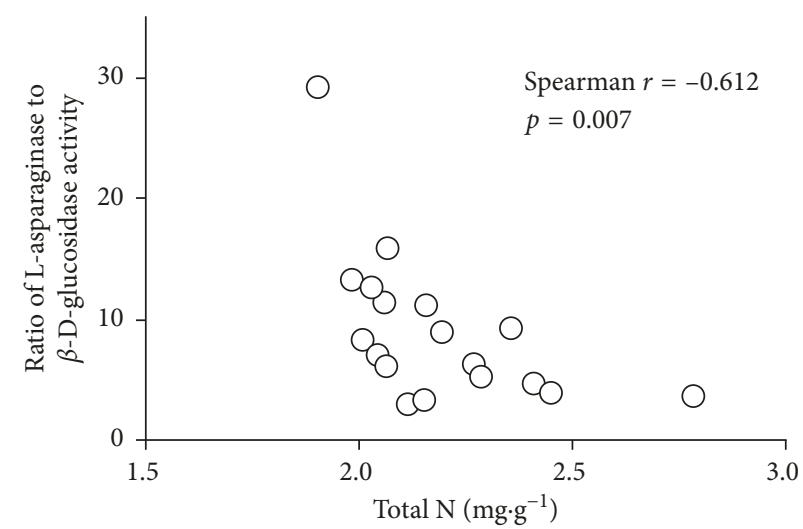

(b)

FIgURE 4: Relationships between Bray-2P and ratio of acid phosphatase to $\beta$-D-glucosidase activity (a) and between total N and ratio of Lasparaginase to $\beta$-D-glucosidase activity (b) in paddy soil.

indicating that acid phosphatase and L-asparaginase were synthesized by microorganisms depending on the temporal changes in soil $\mathrm{P}$ and $\mathrm{N}$ availabilities, although the microbial community is known to vary substantially with redox conditions in paddy soils. These results suggest the significance of soil temperature in controlling in situ enzyme activities in the paddy soil and also that the stoichiometry of extracellular enzyme activity associated with $\mathrm{C}, \mathrm{N}$, and $\mathrm{P}$ acquisition reflects the soil nutrient availability. Further studies are needed to confirm the usefulness of the stoichiometry of extracellular enzyme activity as an index of nutrient availability in paddy soils.

\section{Data Availability}

The data used to support the findings of this study are available from the corresponding author upon request.

\section{Conflicts of Interest}

The authors declare that they have no conflicts of interest.

\section{Acknowledgments}

This study was supported by the Management Expenses Grant from Shinshu University.

\section{References}

[1] N. K. Fageria, N. A. Slaton, and V. C. Baligar, "Nutrient management for improving lowland rice productivity and sustainability," Advances in Agronomy, vol. 80, pp. 63-152, 2003.

[2] K. Kyuma, Paddy Soil Science, Kyoto University Press, Kyoto, Trans Pacific Press, Melbourne, Australia, 2004.

[3] FAO, The International Year of Rice 2004: Concept Paper, FAO, Rome, Italy, 2003.

[4] FAO, Rice and Human Nutrition, FAO, Rome, Italy, 2004.

[5] M. Kimura, "Anaerobic microbiology in waterlogged rice fields," in Soil Biochemistry, J.-M. Bollag and G. Stotzky, Eds., vol. 10, pp. 35-138, Marcel Dekker, New York, NY, USA, 2000 .
[6] I. Kögel-Knabner, W. Amelung, Z. Cao et al., "Biogeochemistry of paddy soils," Geoderma, vol. 157, no. 1-2, pp. 1-14, 2010.

[7] I. Watanabe and C. Furusaka, "Microbial ecology of flooded rice soils," in Advances in Microbial Ecology, M. Alexander, Ed., vol. 4, pp. 125-168, Plenum Press, New York, NY, USA, 1980.

[8] T. Yoshida, "Microbial metabolism of flooded soils," in Soil Biochemistry, E. A. Paul and A. D. McLaren, Eds., vol. 3, pp. 83-122, Marcel Dekker, New York, NY, USA, 1975.

[9] M. D. Wallenstein and R. G. Burns, "Ecology of extracellular enzyme activities and organic matter degradation in soil: a complex community-driven process," in Methods of Soil Enzymology, R. P. Dick, Ed., pp. 35-55, Soil Science Society of America, Madison, WI, USA, 2011.

[10] R. P. Dick, "Soil enzyme activities as integrative indicators of soil health," in Biological Indicators of Soil Health, C. E. Pankhurst, B. M. Doube, and V. V. S. R. Gupta, Eds., pp. 121-156, CAB International, Wallingford, UK, 1997.

[11] Y. Onikura and S. Goto, "Soil redox potential," in Analytical Methods for Soil Nutrients, Committee for Analytical Methods for Soil Nutrients, Ed., pp. 53-69, Yokendo, Tokyo, Japan, 1970, in Japanese.

[12] K. R. Reddy and R. D. DeLaune, Biogeochemistry of Wetlands: Science and Applications, CRC Press, Boca Raton, FL, USA, 2008.

[13] H. E. Allen, G. Fu, and B. Deng, "Analysis of acid-volatile sulfide (AVS) and simultaneously extracted metals (SEM) for the estimation of potential toxicity in aquatic sediments," Environmental Toxicology and Chemistry, vol. 12, no. 8, pp. 1441-1453, 1993.

[14] J. W. Morse and D. Rickard, "Chemical dynamics of sedimentary acid volatile sulfide," Environmental Science and Technology, vol. 38, no. 7, pp. 131A-136A, 2004.

[15] T. Kunito, K. Saeki, H. Oyaizu, and S. Matsumoto, "Influences of copper forms on the toxicity to microorganisms in soils," Ecotoxicology and Environmental Safety, vol. 44, no. 2, pp. 174-181, 1999.

[16] T. Kunito, H. Toya, H. Sumi et al., "Evaluating the effects of metals on microorganisms in flooded paddy soils using the SEM/AVS-based approach and measurements of exchangeable metal concentrations," Archives of Environmental Contamination and Toxicology, vol. 72, no. 3, pp. 402-417, 2017. 
[17] Y. Takai and T. Kamura, "The mechanism of reduction in waterlogged paddy soil," Folia Microbiologica, vol. 11, no. 4, pp. 304-313, 1966.

[18] M. Nanzyo, "Available phosphorus," in Analytical Methods for Soil Environment, Editorial Committee for Analytical Methods for Soil Environment, Ed., pp. 267-273, Hakuyusha, Tokyo, Japan, 1997, in Japanese.

[19] J. Murphy and J. P. Riley, "A modified single solution method for the determination of phosphate in natural waters," Analytica Chimica Acta, vol. 27, pp. 31-36, 1962.

[20] M. A. Tabatabai, "Soil enzymes," in Methods of Soil Analysis, Part 2, Microbiological and Biochemical Properties, R. W. Weaver, S. Angle, P. Bottomley et al., Eds., pp. 775-833, Soil Science Society of America, Madison, WI, USA, 1994.

[21] S. Kanazawa and H. Kiyota, "Estimation of L-glutaminase and L-asparaginase activities in soils by the indophenol method," Soil Science and Plant Nutrition, vol. 41, no. 2, pp. 305-311, 1995.

[22] K. Fujita, T. Kunito, J. Matsushita et al., "Nitrogen supply rate regulates microbial resource allocation for synthesis of nitrogen-acquiring enzymes," PLoS One, vol. 13, no. 8, Article e0202086, 2018.

[23] T. Kunito, M. Tsunekawa, S. Yoshida et al., "Soil properties affecting phosphorus forms and phosphatase activities in Japanese forest soils: soil microorganisms may be limited by phosphorus," Soil Science, vol. 177, no. 1, pp. 39-46, 2012.

[24] T. Kunito, T. Tobitani, H. Moro, and H. Toda, "Phosphorus limitation in microorganisms leads to high phosphomonoesterase activity in acid forest soils," Pedobiologia, vol. 55, no. 5, pp. 263-270, 2012.

[25] Y. Lu, A. Watanabe, and M. Kimura, "Input and distribution of photosynthesized carbon in a flooded rice soil," Global Biogeochemical Cycles, vol. 16, no. 4, p. 1085, 2002.

[26] T. Yamagishi, J. Watanabe, K. Okada, T. Hayashi, A. Kumura, and Y. Murata, "Cycling of carbon in a paddy field. II. Biomass and gross production of algae," Japanese Journal of Crop Science, vol. 49, no. 1, pp. 146-155, 1980.

[27] H. Sumi, T. Kunito, Y. Ishikawa, K. Nagaoka, H. Toda, and Y. Aikawa, "Effects of adding alkaline material on the heavy metal chemical fractions in soil under flooded and nonflooded conditions," Soil and Sediment Contamination: An International Journal, vol. 23, no. 8, pp. 899-916, 2014.

[28] G. Sposito, The Chemistry of Soils, Oxford University Press, New York, NY, USA, 2nd edition, 2008.

[29] F. N. Ponnamperuma, "The chemistry of submerged soils," Advances in Agronomy, vol. 24, pp. 29-96, 1972.

[30] J. Bradley, I. Vimpany, and P. J. Nicholls, "Effects of waterlogging and subsequent drainage of a pasture soil on phosphate sorption, extractable phosphate and oxalate-extractable iron," Australian Journal of Soil Research, vol. 22, no. 4, pp. 455-461, 1984.

[31] H. Shiga, "Effect of phosphorus fertility of soils and phosphate application on rice culture in cool region. Part 1. Measurement of phosphorus supplying ability of paddy soils," Research Bulletin of the Hokkaido National Agricultural Experiment Station, vol. 105, pp. 31-49, 1973.

[32] T. S. Verma and B. R. Tripathi, "Evaluation of chemical methods for the determination of available phosphorus in waterlogged Alfisols: 1. Phosphate-availability indices in relation to phosphate fractions," Soil Science, vol. 134, no. 4, pp. 258-264, 1982.

[33] M. Aoki, "Studies on the behavior of soil phosphoric acid under paddy field condition (I)," Journal of the Science of Soil and Manure, vol. 15, pp. 182-201, 1941, in Japanese.
[34] W. H. Patrick Jr. and I. C. Mahapatra, "Transformation and availability to rice of nitrogen and phosphorus in waterlogged soils," Advances in Agronomy, vol. 20, pp. 323-359, 1968.

[35] G. Kirk, The Biogeochemistry of Submerged Soils, John Wiley \& Sons, Chichester, UK, 2004.

[36] S. Gotoh and K. Yamashita, "Oxidation-reduction potential of a paddy soil in situ with special reference to the production of ferrous iron, manganous manganese and sulfide," Soil Science and Plant Nutrition, vol. 12, no. 6, pp. 230-238, 1966.

[37] I. R. Phillips, "Phosphorus availability and sorption under alternating waterlogged and drying conditions," Communications in Soil Science and Plant Analysis, vol. 29, no. 19-20, pp. 3045-3059, 1998.

[38] M. Wallenstein, S. D. Allison, J. Ernakovich, J. M. Steinweg, and R. Sinsabaugh, "Controls on the temperature sensitivity of soil enzymes: a key driver of in situ enzyme activity rates," in Soil Enzymology, G. Shukla and A. Varma, Eds., pp. 245-258, Springer-Verlag, Berlin, Germany, 2011.

[39] G. P. McLatchey and K. R. Reddy, "Regulation of organic matter decomposition and nutrient release in a wetland soil," Journal of Environmental Quality, vol. 27, no. 5, pp. 12681274, 1998.

[40] I. D. Pulford and M. A. Tabatabai, "Effect of waterlogging on enzyme activities in soils," Soil Biology and Biochemistry, vol. 20, no. 2, pp. 215-219, 1988.

[41] X.-C. Wang and Q. Lu, "Effect of waterlogged and aerobic incubation on enzyme activities in paddy soil," Pedosphere, vol. 16, no. 4, pp. 532-539, 2006.

[42] H. Ishida and M. Shiraishi, "Enzyme activity in paddy soils," Soil Microorganisms, vol. 20, pp. 11-18, 1978, in Japanese.

[43] S. Kanazawa, "Soil enzyme in paddy soil," Pedologist, vol. 24, pp. 69-93, 1980, in Japanese.

[44] C. Freeman, N. Ostle, and H. Kang, "An enzymic "latch" on a global carbon store," Nature, vol. 409, p. 149, 2001.

[45] N. Fenner and C. Freeman, "Drought-induced carbon loss in peatlands," Nature Geoscience, vol. 4, no. 12, pp. 895-900, 2011.

[46] N. Fenner and C. Freeman, "Carbon preservation in humic lakes; a hierarchical regulatory pathway," Global Change Biology, vol. 19, no. 3, pp. 775-784, 2013.

[47] R. L. Sinsabaugh and J. J. Follstad Shah, "Ecoenzymatic stoichiometry and ecological theory," Annual Review of Ecology, Evolution, and Systematics, vol. 43, no. 1, pp. 313343, 2012.

[48] R. L. Sinsabaugh and D. L. Moorhead, "Resource allocation to extracellular enzyme production: a model for nitrogen and phosphorus control of litter decomposition," Soil Biology and Biochemistry, vol. 26, no. 10, pp. 1305-1311, 1994.

[49] K. Fujita, T. Kunito, H. Moro, H. Toda, S. Otsuka, and K. Nagaoka, "Microbial resource allocation for phosphatase synthesis reflects the availability of inorganic phosphorus across various soils," Biogeochemistry, vol. 136, no. 3, pp. 325-339, 2017.

[50] H. Moro, T. Kunito, and T. Sato, "Assessment of phosphorus bioavailability in cultivated Andisols from a long-term fertilization field experiment using chemical extractions and soil enzyme activities," Archives of Agronomy and Soil Science, vol. 61, no. 8, pp. 1107-1123, 2015.

[51] H. Itoh, S. Ishii, Y. Shiratori et al., "Seasonal transition of active bacterial and archaeal communities in relation to water management in paddy soils," Microbes and Environments, vol. 28 , no. 3, pp. $370-380,2013$. 

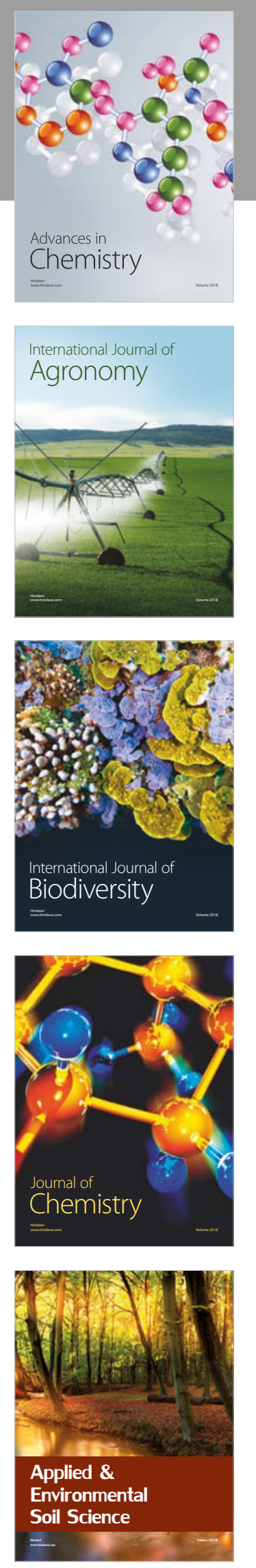

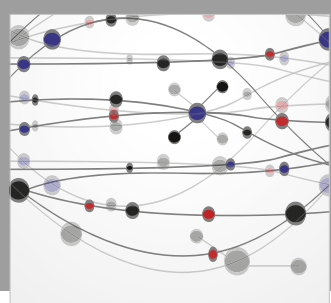

The Scientific World Journal

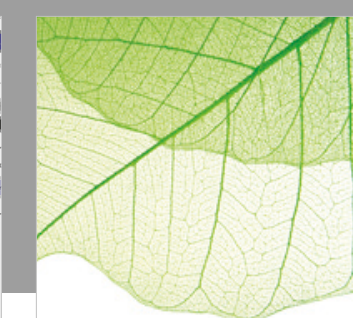

Journal of Botany

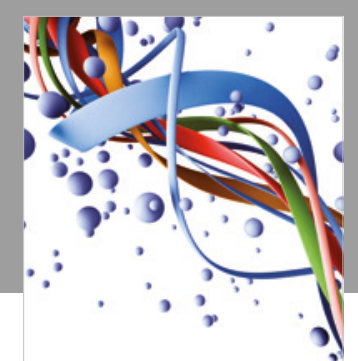

Scientifica

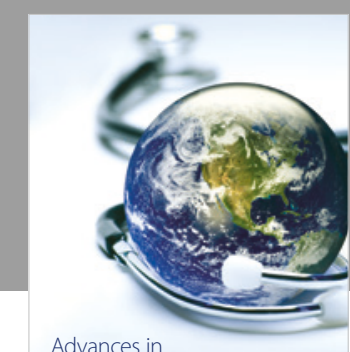

Public Health

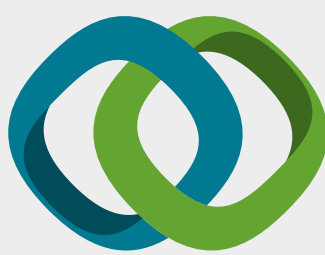

Hindawi

Submit your manuscripts at

www.hindawi.com
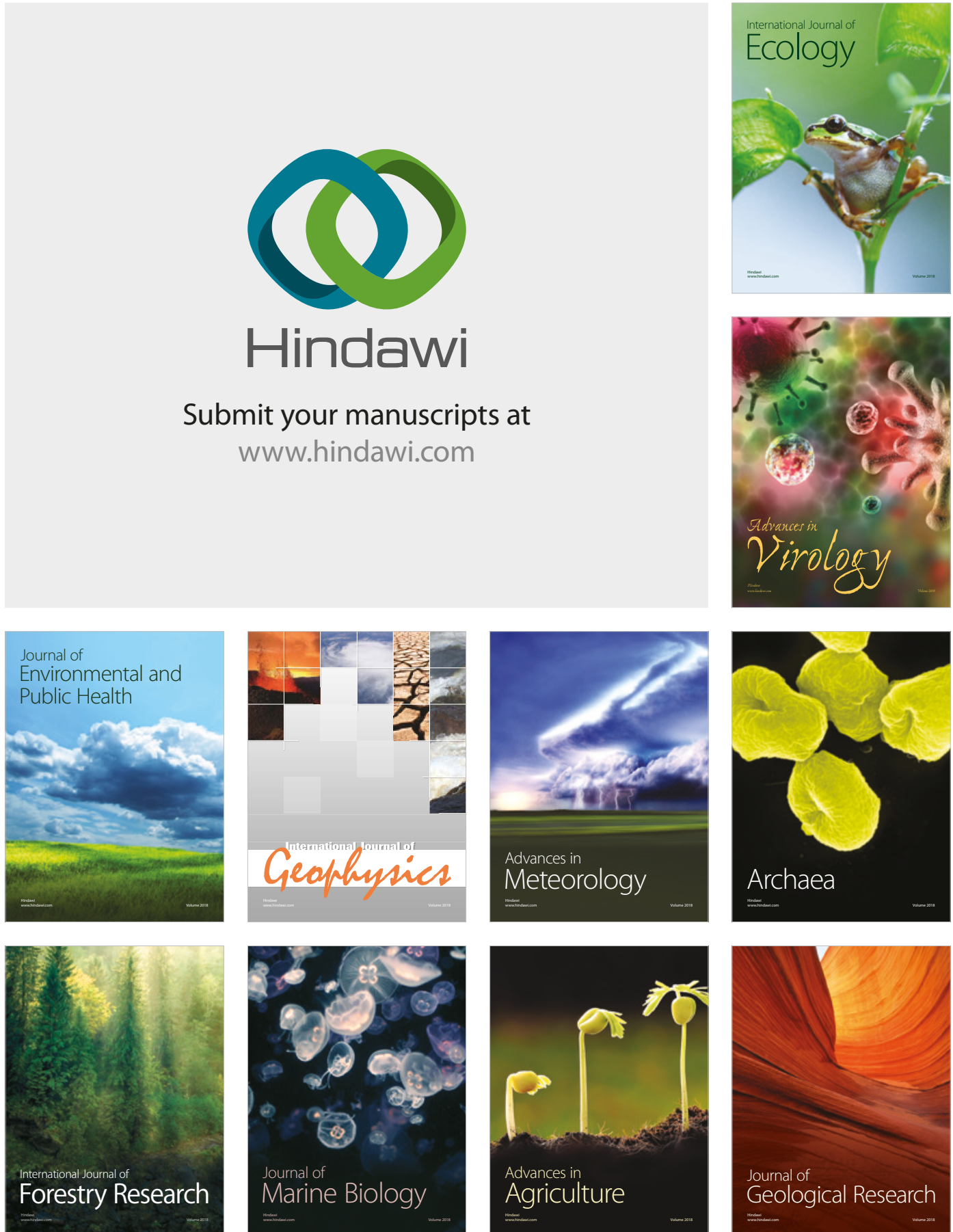

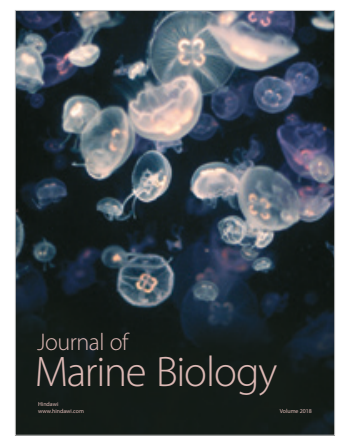

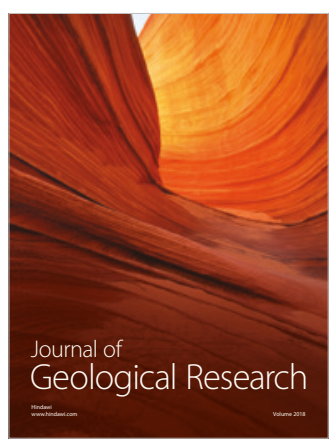

